\title{
PENENTUAN KOMODITAS UNGGULAN PERIKANAN TANGKAP DI PERAIRAN PROVINSI KEPULAUAN BANGKA BELITUNG
}

\author{
Determination Superior Comodity of Capture Fisheries in Bangka Belitung Province
}

\author{
Oleh: \\ Dersi Herka Mayu¹, Dian Wijayanto², Abdul Kohar Mudzakir³, Kurniawan \\ 1Program Pascasarjana Manajemen Sumberdaya Pantai, Fakultas Perikanan dan Ilmu Kelautan Universitas Diponegoro. \\ dersidhm34@gmail.com \\ 2Departemen Perikanan Tangkap, Fakultas Perikanan dan Ilmu Kelautan, Universitas Diponegoro. \\ dianwijayanto@gmail.com \\ ${ }^{3}$ Departemen Perikanan Tangkap, Fakultas Perikanan dan Ilmu Kelautan, Universitas Diponegoro. \\ akoharmud@gmail.com \\ ${ }^{4}$ Manajemen Sumberdaya Perairan, Fakultas Pertanian, Perikanan dan Biologi. Universitas Bangka Belitung. \\ awal.rizka@yahoo.com \\ *Korespondensi: dersidhm34@gmail.com
}

Diterima: 16 Desember 2020; Disetujui: 31 Mei 2021

\begin{abstract}
Bangka Belitung is an archipelagic province consisting of 954 islands with 218.236 tonnes capture fisheries potential. As a leading economic sector in the region, capture fisheries should be maintained sustainably. One of actions that can be done is focusing fisheries development on prime commodities. Purpose of this study were to identify prime commodities and potential commodities in Bangka Belitung waters. Location Quotient (LQ) Analysis, Shift Share (SS), and Specialization Index (SI) were used for data analysis. The result showed that there were three prime commodities i.e., red snapper (Lutjanus campecanus), mackerel (Scomberomorus commerson), and blue swimming crab (Portunus pelagicus). Other potential fisheries commodities in Bangka Belitung Province were grouper (Plectropomus leopardus), yellowtail (Caesio erythrogaster), sea catfish (Arius thalassinus), fork-tailed threadfin bream (Nemipterus furcocus), stingray (Dasyatis sp), and crab (Scylla serrata).
\end{abstract}

Keywords: Bangka Belitung Province, capture fisheries, prime commodities.

\section{ABSTRAK}

Provinsi Kepulauan Bangka Belitung merupakan wilayah kepulauan dengan jumlah pulau sebanyak 954 pulau dan potensi perikanan tangkap yang melimpah sebesar 218.236 ton. Kondisi yang demikian menjadikan sektor perikanan di Provinsi Kepulauan Bangka Belitung sebagai sektor unggulan. Besarnya potensi perikanan di perairan Provinsi Kepulauan Bangka Belitung harus dimanfaatkan dengan optimal dan berkelanjutan. Strategi yang dapat dilakukan adalah dengan penentuan komoditas unggulan untuk kemudian dapat fokus pengembangan pada komoditas unggulan tersebut. Tujuan penelitian ini untuk mengidentifikasi komoditas unggulan dan komoditas potensial di perairan Provinsi Kepulauan Bangka Belitung. Metode penelitian menggunakan analisis Location Quotient (LQ), Shift Share (SS) dan Specialization Index (SI). Hasil analisis menunjukkan tiga komoditas unggulan di perairan Provinsi Kepulauan Bangka Belitung yaitu ikan kakap merah (Lutjanus campecanus), tenggiri (Scomberomorus commerson) dan rajungan (Portunus pelagicus). Komoditas potensial di perairan Provinsi Kepulauan Bangka Belitung adalah ikan kerapu sunu (Plectropomus leopardus), ekor kuning (Caesio erythrogaster), manyung (Arius thalassinus), kurisi merah (Nemipterus furcocus), pari (Dasyatis sp) dan kepiting (Scylla Serrata). 
Kata kunci: Komoditas unggulan, perikanan tangkap, Provinsi Bangka Belitung

\section{PENDAHULUAN}

Provinsi Kepulauan Bangka Belitung secara geografis dikelilingi dan berbatasan langsung dengan laut lepas sehingga memiliki potensi perikanan tangkap yang melimpah. Pada tahun 2014, produksi perikanan tangkap di Provinsi Kepulauan Bangka Belitung sebesar 203.284 ton, dan pada tahun 2015 menurun menjadi 139.632 ton. Selanjutnya produksi kembali meningkat menjadi sebesar 196.704 ton pada tahun 2016. Peningkatan produksi perikanan kembali terjadi di tahun 2017 menjadi 208.019 ton dan semakin meningkat di tahun 2018 menjadi 228.981 ton (DKP Provinsi Kepulauan Bangka Belitung 2019). Sektor perikanan merupakan salah satu sektor unggulan dikarenakan memiliki jenis komo-ditas ikan dengan minat pasar dan nilai ekonomis yang tinggi. Kontribusi sektor ini mencapai 7,54\% dengan nilai PDRB sebesar Rp.5.717.175.000 dan nilai produksi perikanan tangkap mencapai Rp.8.432.000.000 (BPS Provinsi Kepulauan Bangka Belitung 2019). Komoditas ekspor perikanan tangkap di Provinsi Kepulauan Bangka Belitung adalah ikan tenggiri, rajungan, kakap merah, cumi-cumi, bawal hitam, kerapu sunu dan manyung (BKIPM 2019).

Penentuan komoditas ikan unggulan merupakan salah satu langkah awal dalam mewujudkan pembangunan perekonomian secara berkelanjutan. Komoditas unggulan adalah komoditi potensial yang dipandang dapat dipersaingkan dengan produk sejenis di daerah lain, karena disamping memiliki keung-gulan komparatif juga memiliki efisiensi usaha yang tinggi (Hendayana 2003). Dapat dikatakan juga bahwa komoditas unggulan adalah suatu jenis komoditas yang paling diminati dan memiliki nilai jual tinggi sehingga diharapkan mampu memberikan pemasukan yang besar dibandingkan dengan jenis yang lainnya. Dari sisi penawaran, komoditas ikan unggulan ditinjau dari berbagai macam sisi seperti unggulan dalam keadaan biofisik, teknologi, dan sosial ekonomi nelayan serta dapat dijadikan produk andalan untuk mengha-silkan pendapatan yang optimum. Komoditas unggulan sektor perikanan laut merupakan salah satu komoditas strategis untuk mening-katkan pendapatan asli daerah (Irnawati et al. 2011; Ridwan et al. 2018).
Penelitian tentang komoditas unggulan perikanan tangkap sudah banyak dikaji di beberapa Kabupaten di perairan Provinsi Kepulauan Bangka Belitung. Mustaruddin dan Astarini (2020) menyatakan bahwa di cumicumi, udang, kerapu, kakap merah dan tenggiri sebagai sumberdaya ikan unggulan di perairan Kabupaten Bangka Selatan. Kurniawan et al. (2020) menyatakan bahwa terdapat komoditas unggulan perikanan tangkap di perairan pulau Bangka, yaitu ikan tetengkek (Megalaspis cordyla), bawal hitam (Formio niger), kerapu karang (Cephalopholis bunack), cucut tikus/monyet (Alopias pelagicus), pari kembang/macan (Amphotistus kuhlii) dan cumi-cumi (Loligo $s p$.)

Tujuan RPJMD Provinsi Kepulauan Bangka Belitung Tahun 2017-2022 yaitu "Meningkatkan PDRB Sub Sektor Perikanan, Indikator: Laju Pertumbuhan PDRB Sub Sektor Perikanan". Merujuk RPJMD, Rencana Strategis (RENSTRA) Dinas Kelautan dan Perikanan Provinsi Kepulauan Bangka Belitung Tahun 2017-2022 adalah: 1) mengop-timalkan pembangunan dan pengelolaan berbasis pengembangan wilayah kelautan dan perikanan, dan 2) meningkatkan produktivitas kelautan dan perikanan. Salah satu langkah dalam meningkatkan PDRB sub sektor perikanan, adalah dengan adanya komoditas unggulan daerah sehingga dapat dijadikan komoditas yang memiliki daya saing dan strategis untuk kemudian dapat fokus pengembangan pada komoditas unggulan tersebut. Dengan demikian, tujuan penelitian ini untuk mengidentifikasi komoditas unggulan dan potensial di perairan Provinsi Kepulauan Bangka Belitung.

\section{METODE}

Penelitian ini dilaksanakan pada bulan September hingga Oktober 2020. Pengambilan data primer dilakukan di 7 (tujuh) Kabupaten/Kota di Provinsi Kepulauan Bangka Belitung. Penelitian ini dilakukan dengan menggunakan metode deskriptif. Jenis dan sumber data yang digunakan dalam penelitian ini adalah harga, potensi, ekspor dan kontinuitas produksi suatu jenis ikan terhadap komoditas unggulan di Provinsi Kepulauan Bangka Belitung. Data tersebut 
diperoleh dengan metode observasi dan wawancara dengan pihak-pihak terkait antara lain Dinas Kelautan dan Perikanan Provinsi Kepulauan Bangka Belitung, Badan Karantina Ikan Pengendalian Mutu Provinsi Kepulauan Bangka Belitung, nelayan dan penjual produk hasil perikanan. Selain itu juga dibutuhkan data pendukung yang diperoleh dari Dinas Kelautan dan Perikanan Provinsi Kepulauan Bangka Belitung, Badan Karantina Ikan Pengendalian Mutu Provinsi Kepulauan Bangka Belitung, Kementerian Kelautan dan Perikanan Indonesia dan Badan Pusat Statistik Provinsi Kepulauan Bangka Belitung. Data pendukung yang dimaksud adalah: 1) Data produksi per jenis ikan tahun 2014-2018 di Provinsi Kepulauan Bangka Belitung, 2) Data produksi per jenis ikan tahun 2014-2018 Indonesia, 3) PDRB Provinsi Kepulauan Bangka Belitung, 4) PDRB di Indonesia.

Analisis data dilakukan untuk menentukan komoditas unggulan dan komoditas potensial di perairan Provinsi Kepulauan Bangka Belitung, yaitu dengan menggunakan metode analisis data yang bersifat deskriptif. Menurut Sugiyono (2013) mengatakan bahwa analisis deskriptif adalah data statistik yang digunakan untuk menganalisa data dengan cara mendeskripsikan atau menggambarkan data yang telah dihasilkan dengan proses analisa. Metode pengolahan data dimulai dari data yang telah dikumpulkan diolah dengan cara penyuntingan dan pengelompokkan sesuai dengan kebutuhan analisis selanjutnya dengan tabulasi, kuantitatif dan deskriptif sesuai dengan tujuan penelitian.

Analisis Location Quotient (LQ), Analisis Shift Share (SS) dan Analisis Specialization Index (SI) digunakan untuk menganalisis data yang telah dikumpulkan dalam penentuan komoditas unggulan di Provinsi Kepulauan Bangka Belitung. Metode analisis LQ, SS dan SI menggunakan perbandingan antara wilayah. Wilayah analisis adalah wilayah/ daerah yang penelitian yaitu Provinsi Kepulauan Bangka Belitung. Wilayah referensi adalah wilayah yang memiliki cakupan lebih besar dari wilayah analisis yang dijadikan sebagai pembanding yaitu Indonesia.

Analisis Location Quotient digunakan untuk mengidentifikasi dan membandingkan peranan konsentrasi produksi jenis ikan di suatu wilayah (Tarigan 2005). Perhitungan LQ menunjukkan suatu perbandingan antara suatu sektor atau jenis pada suatu daerah terhadap besarnya peranan sektor atau jenis tersebut pada daerah yang dijadikan referensi. Nilai LQ diperoleh dari:

$\mathrm{LQ}=\frac{X i j / X j}{X i n / X n}$

Dimana:

Xij = Produksi jenis ikan i pada Provinsi Kepulauan Bangka Belitung

$\mathrm{Xj}=$ Total produksi pada Provinsi Kepulauan Bangka Belitung

Xin $=$ Produksi jenis ikan i pada Indonesia

$\mathrm{Xn}=$ Total produksi pada Indonesia

Adapun kriteria yang digunakan untuk analisis LQ, sebagai berikut:

- Jika $L Q>1$, berarti komoditas yang bersangkutan produksinya dapat memenuhi kebutuhan sendiri karena komoditas tersebut dalam perekonomian daerah mempunyai keunggulan komparatif dan dikategorikan sebagai komoditas basis.

- Jika $L Q=1$, berarti komoditas yang bersangkutan produksinya pada tingkat daerah, memiliki kesamaan dengan komoditas yang sama pada tingkat provinsi.

- Jika $L Q<1$, berarti komoditas yang bersangkutan produksinya belum dapat memenuhi kebutuhan sendiri karena komoditas tersebut dalam perekonomian daerah tidak mempunyai keunggulan komparatif dan dikategorikan sebagai komoditas non basis.

Analisis Shift Share (SS) digunakan untuk menunjukkan sektor yang berkembang pada suatu wilayah dengan membandingkan dengan daerah yang lebih besar (regional atau nasional). Shift share berfungsi menunjukkan komoditas yang berkembang di Provinsi Kepulauan Bangka Belitung dibandingkan dengan Indonesia sebagai daerah pemban-ding. Ridwan et al. (2018), analisis SS menunjukkan perbandingan perubahan regional yang terjadi disuatu wilayah dan wilayah yang cakupan lebih luas (referensi). Analisis ini juga digunakan untuk menganalisis perubahan struktur ekonomi suatu wilayah terhadap wilayah referensi.

Formula yang digunakan untuk shift share (Muta 2019), sebagai berikut:

$\Delta \mathrm{Y}=\mathrm{PS}+\mathrm{P}+\mathrm{D}$

$P S=E_{i j} \times R_{n}$

$P=E_{i j}\left(R_{i n}-R_{n}\right)$

$D=E_{i j}\left(R_{i j}-R_{i n}\right)$

Dimana: 
$\Delta \mathrm{Y}=$ Shif Share wilayah analisis kategori kei

PS = Provincial Share wilayah analisis kategori ke-i

$\mathrm{P}=$ Proportional Shift wilayah analisis kategori ke-i

$\mathrm{D}=$ Differential Shift wilayah analisis kategori ke-i

Eij = PDRB wilayah analisis sektor/jenis ikan ke-i

$\mathrm{Rn}=$ Pertumbuhan total PDRB wilayah referensi tahun terakhir terhadap total PDRB wilayah referensi tahun sebelumnya

Rin = Pertumbuhan PDRB wilayah referensi sektor ke-i tahun terakhir terhadap PDRB wilayah referensi sektor ke-i tahun sebelumnya

Rij = pertumbuhan PDRB wilayah analisis sektor ke-i tahun terakhir terhadap PDRB wilayah analisis sektor ke-i tahun sebelumnya.

Apabila,

- Proportional Shift $(\mathrm{P})$ bernilai positif berarti sektor tersebut berkembang dan jika negatif berarti mengalami penurunan

- Differential Shift (D) bernilai positif berarti daya saing lebih baik dari daerah/wilayah referensi, sehingga dalam analisis shift share dilihat berdasarkan perbandingan pergesaran nilai proportional shift $(\mathrm{P})$ dan differential shift (D).

Analisis Specialization Index (SI) berfungsi untuk melihat spesialisasi produksi perikanan di Provinsi Kepulauan Bangka Belitung terhadap jenis ikan tertentu di wilayah referensi (Indonesia). Menurut Yurliana et al. (2015) rumus untuk mengetahui nilai SI, sebagai berikut:

$\mathrm{SI}=\left[\frac{v i}{v t}-\frac{v i}{V t}\right] \times 100 \%$

Dimana:

$\mathrm{vi}=$ Produksi jenis ikan A pada Provinsi Kepulauan Bangka Belitung

$\mathrm{vt}=$ Total Produksi pada Provinsi Kepulauan Bangka Belitung

$\mathrm{Vi}=$ Produksi jenis ikan A pada Indonesia

$\mathrm{Vt}=$ Total produksi pada Indonesia

- Jika SI > 100\%, terjadinya spesialisasi produksi perikanan tangkap di Provinsi Kepulauan Bangka Belitung secara relatif dibandingkan dengan Indonesia

- Jika SI < 100\%, tidak terjadinya spesialisasi produksi perikanan tangkap di Provinsi Kepulauan Bangka Belitung secara relatif dibandingkan dengan Indonesia

\section{HASIL}

Berdasarkan hasil analisis menunjukkan bahwa terdapat 20 jenis komoditas ikan perikanan tangkap dengan beberapa dianta-ranya berstatus sebagai komoditas unggulan dan komoditas potensial. Komoditas unggulan merupakan komoditas yang berpotensi dan dapat dipersaingkan dengan produk sejenis di daerah lain. Komoditas ini memiliki keunggulan komparatif dan efisiensi usaha yang tinggi (Masniadi 2012; Susanto 2014). Penentuan komoditas unggulan terdiri dari tiga analisis yaitu Location Quotient (LQ), Shift Share (SS) dan Specialization Index (SI).

Hasil penelitian menujukkan bahwa terdapat tiga jenis ikan yang menjadi komoditas unggulan perikanan tangkap di Provinsi Kepulauan Bangka Belitung yaitu Ikan kakap merah (Lutjanus campecanus), tenggiri (scomberomus commerson) dan rajungan (Portunus pelagicus). Jenis ikan tersebut termasuk komoditas unggulan dikarenakan memenuhi kriteria positif pada setiap analisis yang telah dilakukan baik analisis location quotient (LQ), analisis shift share (SS) maupun analisis specialization index (SI). Keunggulan yang dimiliki juga dilihat dari sisi penawaran misalnya memiliki harga bernilai ekonomis tinggi dan permintaan konsumsi tinggi baik lokal maupun ekspor. Komoditas ungulan perikanan tangkap di perairan Provinsi Kepulauan Bangka Belitung disajikan pada Tabel 2.

Hasil penelitian menunjukkan bahwa terdapat enam jenis ikan yang termasuk ke dalam komoditas potensial karena hanya memenuhi dua dari analisis yang bernilai positif. Komoditas potensial perikanan tangkap di perairan Provinsi Kepulauan Bangka Belitung diantaranya ikan ekor kuning (Caesio erythrogaster), manyung (Arius thalassinus), kurisi merah (Nemipterus furcocus), kerapu sunu (Piectropomus leopardus), pari (Dasyatis sp.) dan kepiting (Scylla serrata) disajikan pada Tabel 3. 
Tabel 1 Komoditas Perikanan Tangkap di Perairan Provinsi Kepulauan Bangka Belitung

\begin{tabular}{|c|c|c|c|c|c|c|c|c|}
\hline No & Jenis Ikan & LQ & $\begin{array}{c}\text { Persamaa } \\
n\end{array}$ & SS & $\begin{array}{c}\text { Persamaa } \\
n\end{array}$ & SI & $\begin{array}{c}\text { Persamaa } \\
n\end{array}$ & $\begin{array}{c}\text { Keteranga } \\
\mathrm{n}\end{array}$ \\
\hline 1. & $\begin{array}{l}\text { Udang (Penaeus } \\
\text { monodon) }\end{array}$ & 0,45 & Non Basis & 142,12 & Cepat & $\begin{array}{l}- \\
465 \\
\%\end{array}$ & $\begin{array}{l}\text { Bukan } \\
\text { Spesialisas } \\
\text { i }\end{array}$ & $\begin{array}{l}\text { Non } \\
\text { Unggulan }\end{array}$ \\
\hline 2. & $\begin{array}{l}\text { Ekor Kuning } \\
\text { (Caesio } \\
\text { erythrogaster) }\end{array}$ & 1,75 & Basis & $-789,25$ & Lambat & $\begin{array}{l}290 \\
\%\end{array}$ & Spesialisas & Potensial \\
\hline 3. & $\begin{array}{l}\text { Manyung (Arius } \\
\text { thalassinus) }\end{array}$ & 1,03 & Basis & 169,93 & Cepat & $40 \%$ & $\begin{array}{l}\text { Bukan } \\
\text { Spesialisas } \\
\text { i }\end{array}$ & Potensial \\
\hline 4. & $\begin{array}{l}\text { Kurisi Merah } \\
\text { (Nemipterus } \\
\text { furcocus) }\end{array}$ & 2,14 & Basis & $-334,39$ & Lambat & $\begin{array}{l}381 \\
\%\end{array}$ & Spesialisas & Potensial \\
\hline 5. & $\begin{array}{l}\text { Belanak } \\
\text { (Moolgarda seheli) }\end{array}$ & 0,64 & Non Basis & $-767,56$ & Lambat & $-72 \%$ & $\begin{array}{l}\text { Bukan } \\
\text { Spesialisas } \\
\text { i }\end{array}$ & $\begin{array}{l}\text { Non } \\
\text { Unggulan }\end{array}$ \\
\hline 6. & $\begin{array}{l}\text { Bawal Hitam } \\
\text { (Parastromateus } \\
\text { niger) }\end{array}$ & 1,14 & Basis & -2.131 & Lambat & $73 \%$ & $\begin{array}{l}\text { Bukan } \\
\text { Spesialisas } \\
\text { i }\end{array}$ & $\begin{array}{l}\text { Non } \\
\text { Unggulan }\end{array}$ \\
\hline 7. & $\begin{array}{l}\text { Beloso (Oxyeleotris } \\
\text { marmorata) }\end{array}$ & 0,15 & Non Basis & $-72,77$ & Lambat & $-56 \%$ & $\begin{array}{l}\text { Bukan } \\
\text { Spesialisas } \\
\text { i }\end{array}$ & $\begin{array}{l}\text { Non } \\
\text { Unggulan }\end{array}$ \\
\hline 8. & $\begin{array}{l}\text { Kuro } \\
\text { (Eleuthernema } \\
\text { tetradactylum) }\end{array}$ & 0,36 & Non Basis & $-635,95$ & Lambat & $-98 \%$ & $\begin{array}{l}\text { Bukan } \\
\text { Spesialisas } \\
\text { i }\end{array}$ & $\begin{array}{l}\text { Non } \\
\text { Unggulan }\end{array}$ \\
\hline 9. & $\begin{array}{l}\text { Gulamah (Jonius } \\
\text { trachycepalus) }\end{array}$ & 0,43 & Non Basis & $-313,68$ & Lambat & $\begin{array}{l}- \\
144 \\
\%\end{array}$ & $\begin{array}{l}\text { Bukan } \\
\text { Spesialisas } \\
\text { i }\end{array}$ & $\begin{array}{l}\text { Non } \\
\text { Unggulan }\end{array}$ \\
\hline 10. & $\begin{array}{l}\text { Kakap Merah } \\
\text { (Lutjanus } \\
\text { campecanus) }\end{array}$ & 1,09 & Basis & 2.648 & Cepat & $\begin{array}{l}192 \\
\%\end{array}$ & Spesialisai & Unggulan \\
\hline 11. & $\begin{array}{l}\text { Kerapu Sunu } \\
\text { (Plectropomus } \\
\text { leopardus) }\end{array}$ & 1,21 & Basis & $-8,24$ & Cepat & $\begin{array}{l}181 \\
\%\end{array}$ & Spesialisas & Potensial \\
\hline 12. & $\begin{array}{l}\text { Kuwe } \\
\text { (Gnathanodon } \\
\text { speciosus) }\end{array}$ & 0,82 & Non Basis & -1.654 & Lambat & $-57 \%$ & $\begin{array}{l}\text { Bukan } \\
\text { Spesialisas } \\
\text { i }\end{array}$ & $\begin{array}{l}\text { Non } \\
\text { Unggulan }\end{array}$ \\
\hline 13. & Pari (Dasyatis sp.) & 2,22 & Basis & -1.977 & Lambat & $\begin{array}{l}187 \\
\%\end{array}$ & Spesialisas & Potensial \\
\hline 14. & $\begin{array}{l}\text { Kepiting (Scylla } \\
\text { serrata) }\end{array}$ & 1,28 & Basis & 615 & Cepat & $60 \%$ & $\begin{array}{l}\text { Bukan } \\
\text { Spesialisas } \\
\text { i }\end{array}$ & Potensial \\
\hline 15. & $\begin{array}{l}\text { Kembung } \\
\text { (Rastrelliger } \\
\text { kanagurta) }\end{array}$ & 0,45 & Non Basis & 551,97 & Cepat & $\begin{array}{l}- \\
608 \\
\%\end{array}$ & $\begin{array}{l}\text { Bukan } \\
\text { Spesialisas } \\
\text { i }\end{array}$ & $\begin{array}{l}\text { Non } \\
\text { Unggulan }\end{array}$ \\
\hline 16. & $\begin{array}{l}\text { Teri (Stolephorus } \\
s p .)\end{array}$ & 0,85 & Non Basis & -1.143 & Lambat & $-4 \%$ & $\begin{array}{l}\text { Bukan } \\
\text { Spesialisas } \\
\text { i }\end{array}$ & $\begin{array}{l}\text { Non } \\
\text { Unggulan }\end{array}$ \\
\hline 17. & $\begin{array}{l}\text { Cumi-cumi (Loligo } \\
\text { sp.) }\end{array}$ & 0,7 & Non Basis & 314,37 & Cepat & $\begin{array}{l}- \\
138 \\
\%\end{array}$ & $\begin{array}{l}\text { Bukan } \\
\text { Spesialisas } \\
i\end{array}$ & $\begin{array}{l}\text { Non } \\
\text { Unggulan }\end{array}$ \\
\hline 18. & $\begin{array}{l}\text { Tenggiri } \\
\text { (Scomberomorus } \\
\text { commerson) }\end{array}$ & 1,28 & Basis & 576,74 & Cepat & $\begin{array}{l}242 \\
\%\end{array}$ & Spesialisas & Unggulan \\
\hline 19. & $\begin{array}{l}\text { Rajungan } \\
\text { (Portunus } \\
\text { pelagicus) }\end{array}$ & 2,37 & Basis & 1.903 & Cepat & $\begin{array}{l}547 \\
\%\end{array}$ & Spesialisas & Unggulan \\
\hline 20. & $\begin{array}{l}\text { Tongkol } \\
\text { (Euthynnus affinis) }\end{array}$ & 0,69 & Non Basis & $-958,14$ & Lambat & $\begin{array}{l}- \\
552 \\
\%\end{array}$ & $\begin{array}{l}\text { Bukan } \\
\text { Spesialisas } \\
\text { i }\end{array}$ & $\begin{array}{l}\text { Non } \\
\text { Unggulan }\end{array}$ \\
\hline
\end{tabular}

Sumber: Data sekunder (diolah), 2020 
Tabel 2 Komoditas Unggulan Perikanan Tangkap

\begin{tabular}{lllllllll}
\hline No. Jenis lkan & LQ & Persamaan & SS & Persamaan & SI & Persamaan & Keterangan \\
\hline 1. & $\begin{array}{l}\text { Kakap Merah } \\
\begin{array}{l}\text { Lutjanus } \\
\text { campecanus) }\end{array}\end{array}$ & 1,09 & Basis & 2.648 & Cepat & $192 \%$ & Spesialisai & Unggulan \\
2. & $\begin{array}{l}\text { Tenggiri } \\
\begin{array}{l}\text { (Scomberomorus } \\
\text { commerson) }\end{array}\end{array}$ & 1,28 & Basis & 576,74 & Cepat & $242 \%$ & Spesialisasi & Unggulan \\
3. $\begin{array}{l}\text { Rajungan } \\
\text { (Portunus } \\
\text { pelagicus) }\end{array}$ & 2,37 & Basis & 1.903 & Cepat & $547 \%$ & Spesialisasi & Unggulan \\
\hline
\end{tabular}

Sumber: Data sekunder (diolah), 2020

Tabel 3 Komoditas Potensial Perikanan Tangkap

\begin{tabular}{|c|c|c|c|c|c|c|c|c|}
\hline No. & Jenis Ikan & LQ & Persamaan & SS & Persamaan & $\mathrm{SI}$ & Persamaan & Rangking \\
\hline 1. & $\begin{array}{l}\text { Ekor Kuning } \\
\text { (Caesio } \\
\text { erythrogaster) }\end{array}$ & 1,75 & Basis & $\overline{789,25}$ & Lambat & $290 \%$ & Spesialisasi & 5 \\
\hline 2. & $\begin{array}{l}\text { Manyung } \\
\text { (Arius } \\
\text { thalassinus) }\end{array}$ & 1,03 & Basis & 169,93 & Cepat & $40 \%$ & $\begin{array}{l}\text { Bukan } \\
\text { Spesialisasi }\end{array}$ & 2 \\
\hline 3. & $\begin{array}{l}\text { Kurisi Merah } \\
\text { (Nemipterus } \\
\text { furcocus) }\end{array}$ & 2,14 & Basis & $\overline{3} 34,39$ & Lambat & $381 \%$ & Spesialisasi & 4 \\
\hline 4. & $\begin{array}{l}\text { Kerapu Sunu } \\
\text { (Plectropomus } \\
\text { leopardus) }\end{array}$ & 1,21 & Basis & $-8,24$ & Lambat & $181 \%$ & Spesialisasi & 3 \\
\hline 5. & $\begin{array}{l}\text { Pari (Dasyatis } \\
\text { sp.) }\end{array}$ & 2,22 & Basis & -1.977 & Lambat & $187 \%$ & Spesialisasi & 6 \\
\hline 6. & $\begin{array}{l}\text { Kepiting } \\
\text { (Scylla } \\
\text { serrata) }\end{array}$ & 1,28 & Basis & 615 & Cepat & $60 \%$ & $\begin{array}{l}\text { Bukan } \\
\text { Spesialisasi }\end{array}$ & 1 \\
\hline
\end{tabular}

\section{PEMBAHASAN}

Hasil analisis, nilai LQ tertinggi sebesar 2,37 sedangkan nilai $L Q$ terendah sebesar 0,15 . Nilai $L Q$ yang lebih dari 1 menunjukkan bahwa komoditas tersebut memiliki keunggulan komperatif wilayah dan berpotensi menjadi komoditas ekspor. Komoditas perikanan tangkap yang mempunyai nilai $L Q$ positif (>1) antara lain ikan ekor kuning $(1,75)$, manyung $(1,03)$, kurisi merah $(2,14)$, bawal hitam $(1,14)$, kakap merah $(1,09)$, kerapu sunu $(1,21)$, pari $(2,22)$, kepiting $(1,28)$, tenggiri $(1,28)$ dan rajungan $(2,37)$. Hal ini menujukkan bahwa konsentrasi produksi jenis ikan ini sudah dapat memenuhi kebutuhan untuk daerahnya sendiri dan dapat menyuplai ke daerah lain/ekspor. Mudzakir et al. (2012) menyatakan bahwa nilai LQ > 1 menandakan bahwa konsentrasi produksi jenis ikan unggulan terjadi pemusatan surplus produksi di wilayah kajian. Pemusatan surplus produksi yang dimaksud bahwa jenis ikan komoditas unggulan tersebut secara jumlah produksi mempunyai jumlah yang lebih besar pada wilayah analisis yaitu Provinsi Kepulauan Bangka Belitung.

Jenis sumberdaya ikan yang memiliki nilai $L Q<1$ yaitu ikan belanak $(0,64)$, beloso
$(0,15)$, kuro $(0,36)$, gulamah $(0,43)$, kuwe $(0,82)$, kembung $(0,45)$, teri $(0,85)$, tongkol $(0,69)$, cumi-cumi $(0,70)$ dan udang $(0,45)$. Nilai $\mathrm{LQ}<1$ merupakan komoditas non basis, hal ini diduga jenis ikan komoditas tersebut di wilayah Provinsi Kepulauan Bangka Belitung kurang produktif dalam memenuhi kebutuhan daerah. Kurniawan et al. (2019) menyatakan bahwa nilai $L Q<1$ menunjukkan bahwa komoditas tersebut tidak termasuk komoditas basis sehingga dalam pemenuhan kebutuhan harus ada pemasukan dari luar daerah. Kurangnya produksi jenis ikan tersebut dikarenakan beberapa faktor diantaranya musim penangkapan ikan, permintaan dan minat konsumen terhadap jenis ikan.

Analisis Shift Share, menunjukkan bahwa Provinsi Kepulauan Bangka Belitung berspesialisasi pada komoditas yang mempunyai nilai komponen differential shift (Dj) positif $(D j>0)$. Jenis ikan yang mempunyai $D j$ positif antara lain udang $(142,12)$, manyung $(169,93)$, kakap merah $(2.648,39)$, kerapu sunu $(8,24)$, tenggiri $(576,74)$ dan rajungan $(1.903,68)$. Nilai Dj positif berarti komoditas perikanan tersebut memiliki daya saing yang tinggi dan pertumbuhan secara produksi lebih cepat dibandingkan wilayah referensi. Ridwan et al. (2018) menyatakan bahwa suatu wila- 
yah yang memiliki sektor-sektor yang tingkat pertumbuhannya lamban akan memperlihatkan pergeseran proporsional yang menurun dan sebaliknya suatu wilayah yang mempunyai sektor-sektor yang tingkat pertumbuhannya tinggi akan memperlihatkan pergeseran yang meningkat.

Jenis ikan yang memiliki nilai Dj negatif seperti ikan ekor kuning, kurisi merah, belanak, bawal hitam, beloso, kuro, gulamah, kuwe, pari, teri dan tongkol. Hal ini berarti jenis-jenis ikan tersebut memilki daya saing yang rendah, pertumbuhan secara produksi lebih lamban sehingga ketersediaan sumber daya stok ikan di perairan sangat terbatas khususnya di perairan Provinsi Kepulauan Bangka Belitung. Analisis ini dapat dikatakan sebagai analisis kontribusi terhadap komoditas karena memiliki peranan dalam pertumbuhan PDRB daerah. Dari sisi ekonomi dilihat bahwa jenis ikan yang memiliki nilai DJ positif diantaranya merupakan komoditas ekspor. $\mathrm{Hal}$ ini sejalan berdasarkan data BKIPM Provinsi Kepulauan Bangka Belitung (2019) menyatakan bahwa komoditas ekspor adalah manyung dengan volume ekspor sebesar $986.670 \mathrm{~kg}$, tenggiri sebesar $350.252 \mathrm{~kg}$, kakap merah sebesar $236.663 \mathrm{~kg}$, kerapu sunu sebesar $290.799 \mathrm{~kg}$ dan rajungan sebesar $244.363 \mathrm{~kg}$. Dari sisi sosial dapat juga dilihat dari kecukupan gizi konsumsi ikan masyarakat di Provinsi Kepulauan Bangka Belitung sangat tinggi. Berdasarkan data DKP Provinsi Kepulauan Bangka Belitung (2019) menunjukkan bahwa Tingkat Konsumsi 61,94 $\mathrm{kg} / \mathrm{kap} /$ tahun angka ini sudah di atas angka nasional 54,49 kg/kap/tahun.

Hasil analisis Indeks Spesialisasi (SI), menunjukkan bahwa terdapat spesialisasi jenis komoditas perikanan tangkap di Provinsi Kepulauan Bangka Belitung diantaranya ikan ekor kuning (290\%), kurisi (381\%), kerapu sunu $(181 \%)$, kakap merah (192\%), tenggiri $(242 \%)$ dan rajungan (547\%). Hal ini berarti jenis-jenis ikan tersebut memiliki spesialisasi produksi di daerah Provinsi Kepulauan Bangka Belitung. Spesialisasi produksi yang dimaksud adalah jenis ikan yang memiliki jumlah produksi tinggi dan biasanya dijadikan ikan hasil tangkapan utama atau ikan target oleh nelayan di Provinsi Kepulauan Bangka Belitung.

Penentuan komoditas unggulan sudah dilakukan di beberapa Kabupaten di Provinsi Kepulauan Bangka Belitung, diantaranya hasil penelitian Kurniawan et al. (2019) menyatakan bahwa terdapat 12 komoditas unggulan perikanan tangkap pada tingkat
Kabupaten Bangka Tengah yaitu ikan Belanak, julung-julung, kembung, selar, tenggiri, cucut botol, cucut lanyam, golokgolok, lidah, gulamah, kepiting bakau, dan rajungan. Berdasarkan hasil analisis LQ, SS dan SI menunjukkan bahwa komoditas unggulan perikanan tangkap di perairan Provinsi Kepulauan Bangka Belitung yaitu ikan kakap merah (Lutjanus campecanus), tenggiri (Scomberomorus commerson) dan rajungan (Portunus pelagicus).

Komoditas unggulan perikanan tangkap yang termasuk ke dalam komoditas basis sub sektor perikanan ini memiliki peranan sebagai salah satu prime mover dalam pertumbuhan ekonomi di Provinsi Kepulauan Bangka Belitung setelah sektor pertambangan dan sektor pertanian. Ramadhani dan Yulhendri (2019) menyatakan bahwa sektor unggulan merupakan sektor basis dan memiliki peranan besar dalam pembangunan perekonomian daerah. Pembangunan ekonomi daerah merupakan suatu sistem dimana pemerintah daerah dan masyarakatnya mengelola sumberdaya-sumberdaya yang ada dan membentuk kerjasama antar stakeholder dalam pengembangan usaha ekonomi daerah. Lumbantobing et al. (2016) menjelaskan bahwa dengan diketahuinya jenis komoditas ikan unggulan maka dapat dijadikan sebagai komoditas kunci dalam pengembangan perikanan tangkap untuk meningkatkan pendapatan dan kontribusi pada perekonomian daerah.

\section{Komoditas Unggulan Perikanan Tangkap Kakap Merah (Lutjanus campecanus)}

Berdasarkan hasil analisis LQ terhadap ikan kakap merah (Gambar 1) memiliki nilai LQ sebesar 1,09. Nilai LQ demikian berarti ikan kakap merah (Lutjanus campecanus), merupakan komoditas basis. Artinya, hasil produksi ikan ini di Provinsi Kepulauan Bangka Belitung mampu untuk memenuhi kebutuhan di wilayahnya sendiri dan mampu menyuplai kebutuhan pada daerah lain. Nilai dari SS dengan nilai pergeseran (Differential Shift) atau Dj sebesar 2.648,39 berarti ikan kakap merah mempunyai daya saing yang lebih tinggi jika dibandingakan dengan wilayah referensi. Begitupun hasil analisis spesialisasi (SI) yaitu sebesar 192\% merupakan nilai tertinggi, berarti di wilayah Provinsi Kepulauan Bangka Belitung jenis ikan kakap merah mempunyai spesialisasi produksi tertinggi jika dibandingkan dengan wilayah referensi. Ikan kakap merah termasuk salah satu jenis ikan bernilai ekonomis tinggi, 
dengan harga per kilogramnya sebesar Rp.70.000. Selain bernilai ekonomis, ikan kakap merah juga termasuk komoditas ekspor dengan Negara tujuan yaitu Malaysia, Singapura dan Taiwan dan volume produksi sebesar 1.278.989 ton (Kementerian Kelautan Perikanan 2019). Natsir dan Latifa (2018) kandungan protein pada ikan kakap sangat diperlukan untuk perkembangan otak dan daya tahan tubuh serta perkembangan indera penglihatan dan sistem kekebalan tubuh.

\section{Tenggiri (Scomberomorus commerson)}

Ikan Tenggiri (Scomberomorus commerson) (Gambar 2) memiliki nilai LQ sebesar 1,28 , nilai $S S$ dengan $D j$ sebesar 576,74 dan nilai SI sebesar $242 \%$. Berdasarkan hasil analisis, ikan tenggiri termasuk komoditas unggulan di perairan Provinsi Kepulauan Bangka Belitung karena memenuhi nilai positif dari setiap analisis. Hal ini dikarenakan ikan tenggiri dapat memenuhi kebutuhan jumlah produksi, memiliki daya saing atau pertumbuhan secara produksi lebih cepat dan tinggi serta memiliki spesialisasi (dominan) jenis ikan di wilayah sendiri maupun untuk daerah lainnya sebagai penyuplai. Hal ini sejalan dengan Kurniawan et al. (2019) bahwa ikan tenggiri termasuk komoditas unggulan pada tingkat Kabupaten Bangka Tengah sehingga menjadi salah satu daerah penyuplai ketersedian stok ikan. Penyebaran daerah penangkapan ikan tenggiri dimulai dari fishing base (PPN Sungailiat), Karang Sembilan, Karang Tinggi, Karang Bahaya, Pulau Toti dan Pulau Tujuh (Bukhari et al. 2017).

Sobari dan Febrianto (2010) menyatakan bahwa distribusi pemasaran ikan tenggiri terdiri 4 saluran pemasaran yaitu saluran pemasaran I (nelayan-perusahaan), saluran pemasaran II (nelayan-pengumpulperusahaan), saluran pemasaran III (nelayanpengumpul-pengecer) dan saluran pemasaran IV (nelayan-pedagang-pengecer). Berdasarkan hasil lapangan, harga ikan tenggiri pada musim puncak sebesar Rp.55.000 hingga Rp.65.000 sedangkan ketika musim biasa dan paceklik dapat mencapai Rp.70.000 sampai Rp.90.000 per kilogram. Ikan tenggiri juga salah satu komoditas ekspor dengan volume produksi sebesar 103.594 ton dengan negara tujuan yaitu Malaysia, Singapura, Hongkong dan Taiwan (BKIPM Provinsi Kepulauan Bangka Belitung 2019). Selain permintaan konsumsi maupun ekspor yang tinggi, ikan tenggiri juga menjadi bahan dasar dalam pembuatan olahan produk hasil perikanan seperti kerupuk, kericu, getas, dan otak-otak/pempek sebagai oleh-oleh khas Provinsi Kepulauan Bangka Belitung dapat dilihat pada Gambar 4.

\section{Rajungan (Portunus pelagicus)}

Hasil analisis Location Quotient/LQ, sumberdaya rajungan (Gambar 3) memiliki nilai tertinggi sebesar 2,37, nilai Differential Shift sebesar 1.903,68, dan nilai Specialization Index yaitu sebesar 547\%. Rajungan termasuk komoditas ungulan karena sebagai komoditas basis, dimana hasil mampu memenuhi kebutuhan di wilayahnya sendiri, memiliki pertumbuhan produksi lebih cepat, spesialisasi produksi dan daya saing yang tinggi. Rajungan merupakan komoditas dengan minat konsumsi yang tinggi baik lokal maupun luar daerah hingga ekspor. Kementerian Kelautan Perikanan (2019) menyatakan bahwa volume produksi sebesar 1.104.451 ton dengan negara tujuan yaitu Australia, Malaysia, Singapura, Thailand, United States. Rajungan memiliki nilai ekonomis tinggi dengan kisaran harga Rp50.000-Rp120.000 per kilogram. Rajungan merupakan hasil tangkapan musiman. Ihsan et al. (2018) menyatakan bahwa musim puncak rajungan berlangsung pada bulan Juni dan September dengan persentase tangkapan tertinggi pada bulan September dan terendah pada Bulan April. Priyambada (2020) menyatakan bahwa musim penangkapan rajungan yakni musim Barat (JanuariFebruari) dan musim Timur (April-Juli).

Rajungan termasuk komoditas ekspor karena memiliki daging yang sangat enak dan dapat diolah menjadi berbagai macam masakan sehingga hewan ini sangat diminati para pencinta seafood (Sudhakar et al. 2009). Olahan produk hasil perikanan merupakan salah satu dari usaha kegiatan perikanan baik diproduksi sendiri (nelayan) dan UMKM. Olahan produk perikanan biasanya dijual sebagai konsumsi rumah tangga dan menjadi oleh-oleh khas Provinsi Kepulauan Bangka Belitung. Produknya berupa makanan dan snack seperti kerupuk, kericu, getas, terasi/belacan, otak-otak/pempek, dan ketam/ rajungan isi. Contoh produk hasil perikanan yang berbahan dasar ikan tenggiri dan rajungan tersaji pada Gambar 4 dan 5. Olahan lain dari rajungan, yang dikenal dengan "kepiting kupas" dimana hanya isi rajungan saja yang di jual ke pasar ekspor dengan harga Rp.140.000 per kilogram. Secara umum, pemasaran produk masih bersifat lokal, sistem online, dan mulai merambah pasar yang lebih besar. 


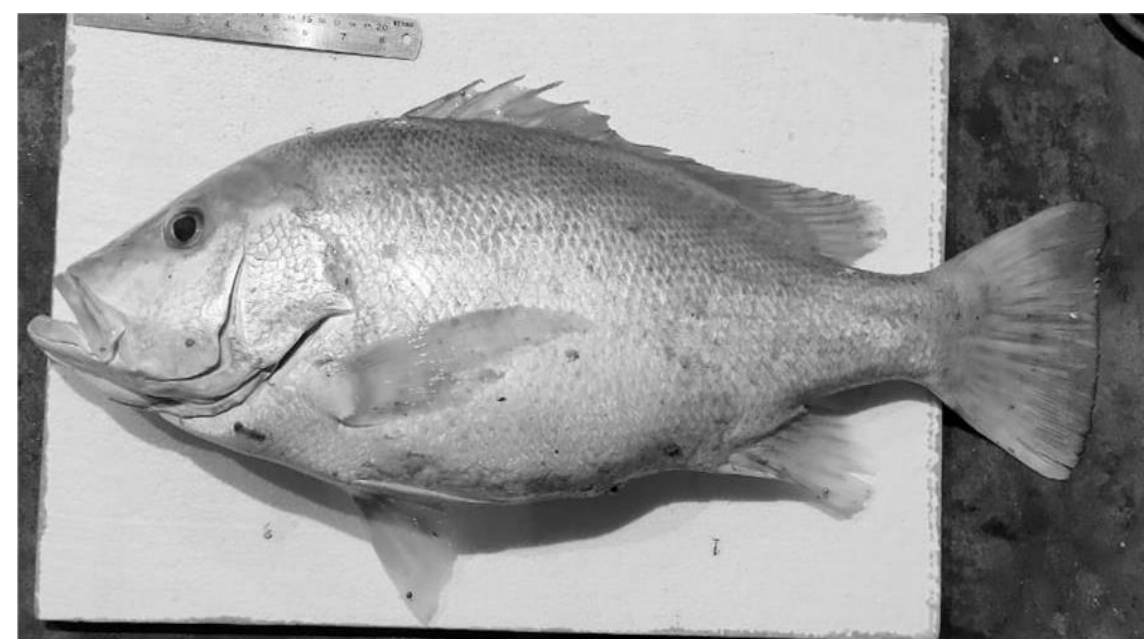

Gambar 1 Kakap Merah (Lutjanus campecanus)

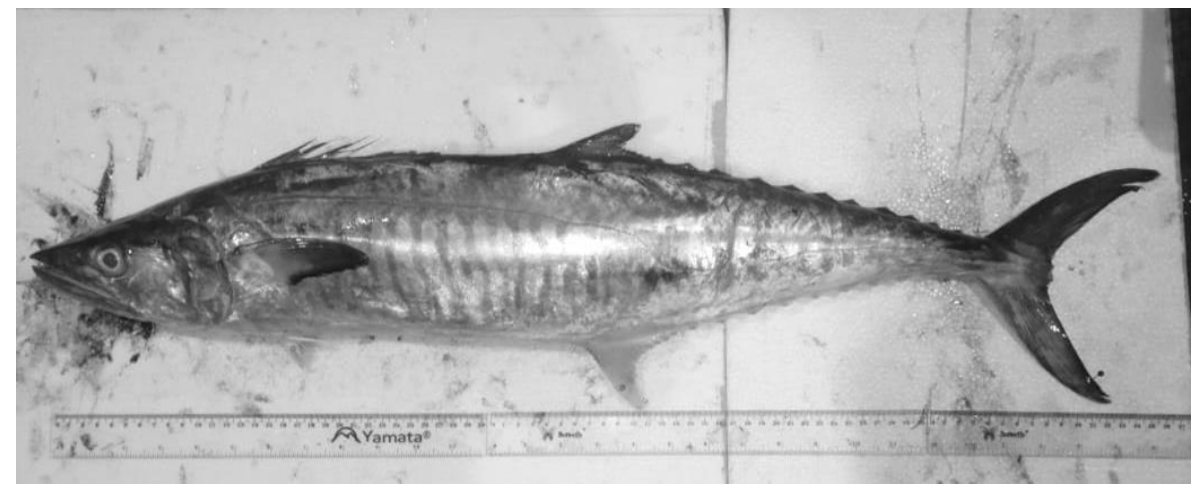

Gambar 2 Tenggiri (Scomberomorus commerson)

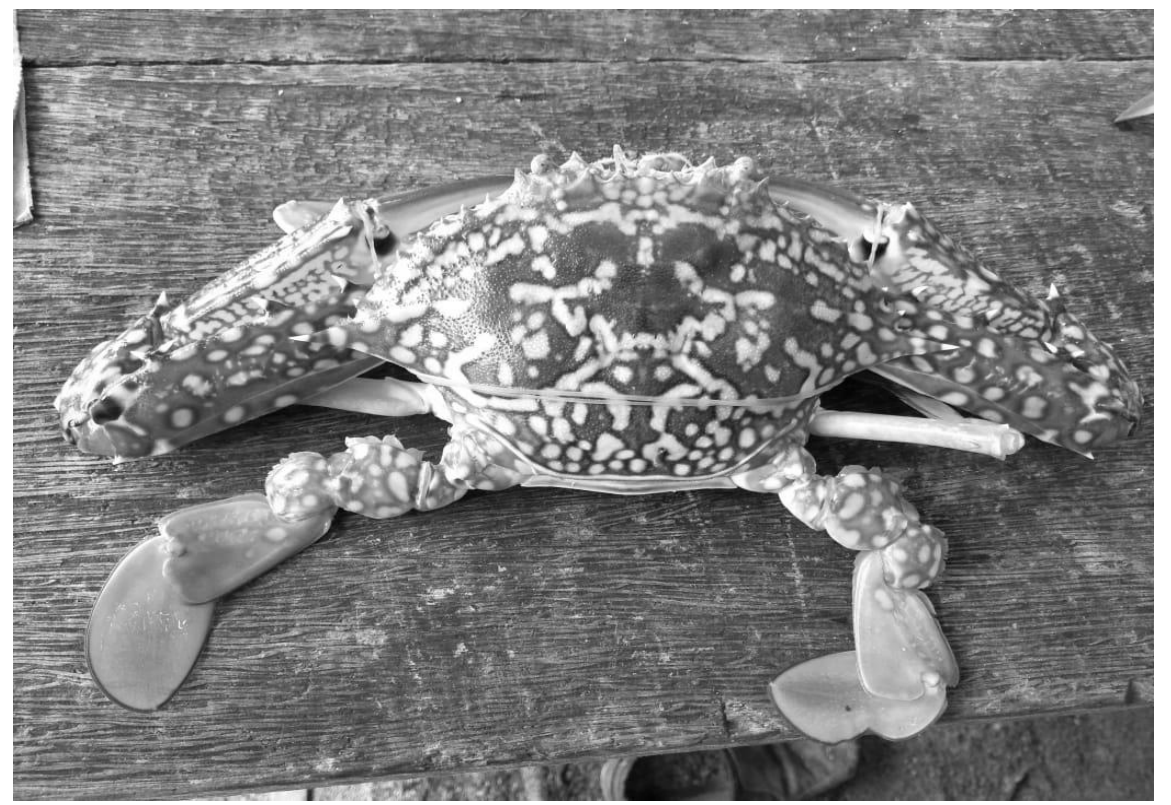

Gambar 3 Rajungan (Portunus pelagicus) 


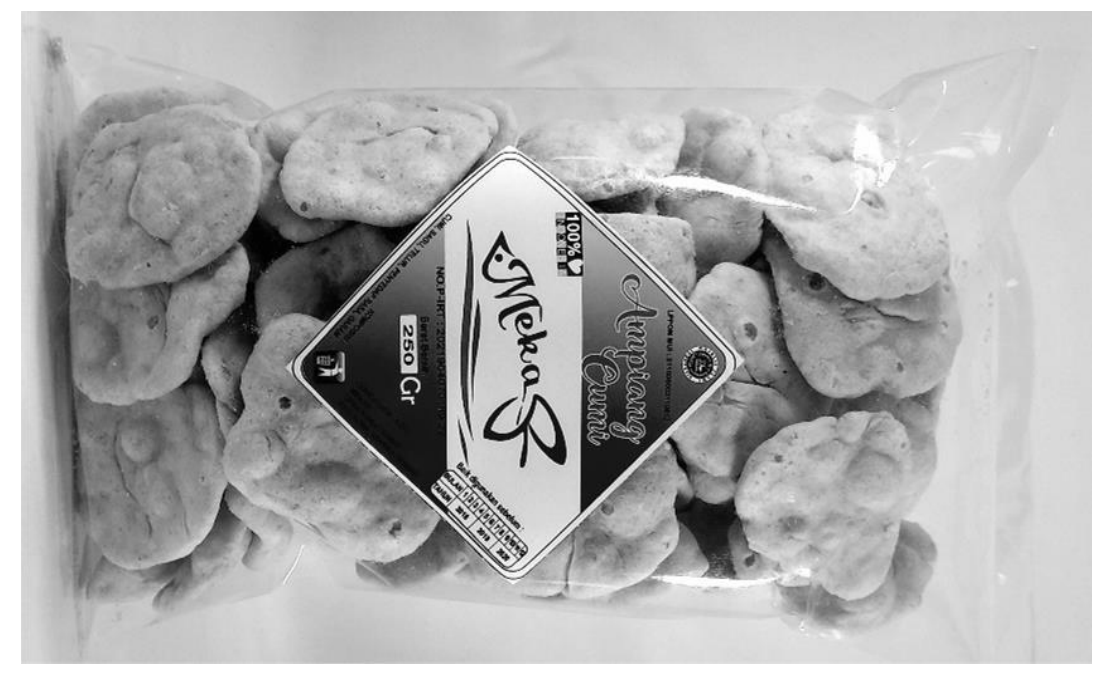

Gambar 4 Produk Olahan Ikan Tenggiri

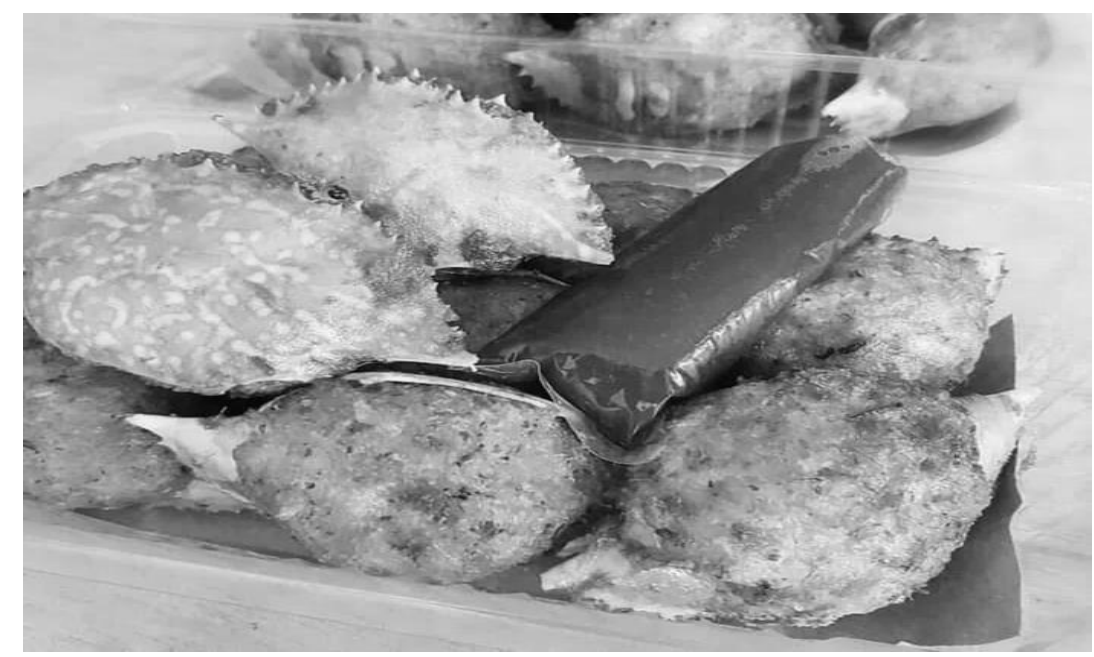

Gambar 5 Produk Ketam Isi (Rajungan)

\section{Komoditas Potensial Perikanan Tangkap}

Berdasarkan Tabel 3 diketahui bahwa jenis ikan komoditas potensial sesuai urutan rangking 1 sampai 6 adalah kepiting, manyung, kerapu sunu, kurasi merah, ekor kuning dan pari. Jenis-jenis ikan tersebut merupakan komoditas ekspor di Provinsi Kepulauan Bangka Belitung. Namun, dari sisi penawaran harga ikan-ikan tersebut masih tergolong bernilai ekonomis rendah seperti ikan ekor kuning sebesar Rp30.000/kg, manyung sebesar Rp25.000/kg, kurasi merah sebesar Rp35.000/kg, dan pari sebesar Rp30.000/kg. Hal ini sejalan dengan hasil analisis SS dimana ikan ekor kuning, kurasi merah dan pari bernilai negatif yang berarti laju pertumbuhan produksi nya rendah.

Kepiting berada pada urutan pertama yang sangat memungkinkan untuk dikembangkan potensinya. Secara umum kepiting atau yang dikenal kepiting bakau merupakan salah satu komoditas budidaya air payau. Menurut Prasetiyono dan Denny (2018) mengatakan bahwa kepiting merupakan komoditas budidaya yang lebih optimal dalam menghasilkan keuntungan dikarenakan komoditas ini memiliki nilai ekspor yang tinggi. Harga kepiting berkisar Rp.90.000 sampai Rp.120.000 per kilogram nya. Komoditas potensial dapat dikembangkan sebagai penggerak perekonomian daerah. Komoditas potensial perikanan tangkap juga dapat diketahui untuk mempermu-dah penentuan strategi dalam pemanfaatan dan pengelolaan perikanan ke depannya.

\section{KESIMPULAN}

Komoditas unggulan perikanan tangkap di perairan Provinsi Kepulauan Bangka Belitung adalah ikan kakap merah (Lutjanus 
campecanus), tenggiri (Scomberomorus commerson) dan rajungan (Portunus pelagicus). Komoditas potensial perikanan tangkap di perarian Provinsi Kepulauan Bangka Belitung adalah ikan kerapu sunu (Plectropomus leopardus), ekor kuning (Caesio erythrogaster), manyung (Arius thalassinus), kurisi merah (Nemipterus furcocus), pari (Dasyatis $s p$ ) dan kepiting (Scylla Serrata).

\section{SARAN}

Pemerintah daerah Provinsi Kepulauan Bangka Belitung perlu berpartisipasi dengan dilakukannya program edukasi atau sosialisasi terhadap pelaku usaha tentang nilai jual terhadap jenis ikan komoditas unggulan sehingga dapat dieksploitasi dalam jangka panjang. Selain itu, perlunya strategi dalam mendorong/mempermudah rantai pemasaran produk komoditas unggulan maupun potensial agar dapat meningkatkan kesejahteraan nelayan dan perekonominan daerah.

\section{UCAPAN TERIMA KASIH}

Penulis mengucapkan terimas kasih kepada Dinas Kelautan dan Perikanan (DKP) dan Badan Pusat Statistik (BPS) Provinsi Kepulauan Bangka Belitung telah berpartisipasi dalam peneilitian ini.

\section{DAFTAR PUSTAKA}

[BKIPM] Badan Karantina Ikan Pengendalian Mutu Provinsi Kepulauan Bangka Belitung. 2019. Volume dan Negara Tujuan Ekspor Provinsi Kepulauan Bangka Belitung. Provinsi Kepulauan Bangka Belitung: BKIPM.

[BPS] Badan Pusat Statistik Provinsi Kepulauan Bangka Belitung. 2019. Provinsi Kepulauan Bangka Belitung dalam Angka 2019. Catalog. 438 hlm.

Bukhari, Wahyu A, Kurniawan. 2017. Pendugaan Daerah Penangkapan Ikan Tenggiri Berdasarkan Distribusi Suhu Permukaan Laut dan Klorofil-a di Perairan Bangka. Jurnal Perikanan Tangkap. 1(3): 1-22.

[DKP] Dinas Kelautan dan Perikanan Provinsi Kepulauan Bangka Belitung. 2019. Statistik Produksi Perikanan Tangkap.
Provinsi Kepulauan Bangka Belitung: DKP.

[DKP] Dinas Kelautan dan Perikanan Provinsi Kepulauan Bangka Belitung. 2019. Rencana Strategis Dinas Kelautan dan Perikanan 2017-2022. Provinsi Kepulauan Bangka Belitung: DKP.

Hendayana R. 2003. Aplikasi Metode Location Quotient (LQ) dalam Penentuan Komoditas Unggulan Nasional. Informatika Pangan. 12(1): 658-675.

Ihsan. 2018. Distribusi Ukuran dan Pola Musim Penangkapan Rajungan (Portunus pelagicus) di Perairan Kabupaten Pangkep. Marine Fisheries. 9(1): 73-83.

Irnawati R, Domu S, Budy W, Bambang M, Tri WN. 2011. Analisis Komoditas Unggulan Perikanan Tangkap di Taman Nasional Karimunjawa. Jurnal Saintek Perikanan. 7(1): 1-9.

[KKP] Kementerian Kelautan dan Perikanan Indonesia. 2019. Data Volume dan Negara Tujuan Ekspor Provinsi Kepulauan Bangka Belitung. Jakarta: KKP.

Kurniawan, Cecep W, Teguh F. 2019. Analisis Komoditas Unggulan Perikanan Tangkap di Kabupaten Bangka Tengah. Jurnal Aquasains. 8(1): 783794.

Kurniawan, Windi AM, Endang B, Christianingrum. 2020. Leading Commodities Analysis of Fisheries in Bangka Regency by using Location Quotient (LQ) Methods, Shift Share Analysis and Klassen Typology. International Journal of Fisheries and Aquatic Research. 4(3): 61-65.

Lumbantobing HF, Agustriani, Isnaini. 2016. Analisis Peranan Subsektor Perikanan Tangkap terhadap Pembangunan Daerah dan Penentuan Komoditas Hasil Tangkapan Unggulan di Kota Sibolga. Maspari Journal. 8(2): 59-72.

Masniadi R. 2012. Analisis Komoditas Ungulan Pertanian untuk Pengembangan Ekonomi Daerah Tertinggal di Kabupaten Sumbawa Barat. Journal of Innovation in Businness and Economics. 3(1): 52-64. 
Mudzakir AK, Danta Paramartha. 2012. Analisis Komoditas Unggulan Perikanan Tangkap di Kabupaten Rembang. Jurnal Harpodon Borneo. 5(2): 161-171.

Mustaruddin, Julia EA. 2020. Observasi Pemanfaatan Sumberdaya Ikan Unggulan dan Strategi Pengembangannya di Perairan Kabupaten Bangka Selatan. Jurnal IImu dan Teknologi Kelautan Tropis. 12(3): 627-641.

Muta, AL. (2019). Dinamika Peran Sektor Pertanian dalam Pembangunan Wilayah di Indonesia. UGM PRESS.

Natsir AN, Latifa Shofia. 2018. Analisis Kandungan Protein Total Ikan Kakap Merah dan Ikan Kerapu Bebek. Jurnal Biologi Science dan Education. 7(1): 49-55.

Prasetiyono E, Denny Syaputra. 2018. Teknologi Polikultur Kepiting Bakau dan Ikan Bandeng pada Kelompok Pembudidaya Ikan Perpat Permai Kelurahan Air Jukung Kecamatan Belinyu Kabupaten Bangka. WARTA LPM. 21(2): 110-121.

Priyambada A. 2020. Size Distribution and Fishing Season of Blue Swimming Crab (Portunus pelagicus) in Tukak Sadai Waters, South Bangka Regency, Indonesia. International Journal of Innovative Research in Advanced Engineering. 7(9): 338-348.
Ramadhani G, Yulhendri. 2019. Analisis Komoditi Unggulan di Kabupaten Solok. EcoGen. 2(3): 472-482.

Ridwan M, Mauli K, Andi RSP. 2018. Penentuan Komoditas Unggulan Perikanan Laut Kabupaten Polewali Mandar berdasarkan data Satistika Tahun 2016. Jurnal IPTEK PSP. 10(1): 98-105.

Sudhakar M, Manivannan K, Soundrapandian P. 2009. Nutritive Value of Hard and Soft Shell Crabs of Portunus Sanguinolentus (Herbst). Jurnal Animal and Veterinary Advances. 1(2): 44-48.

Sugiyono. 2013. Metode Penelitian Kuantitatif dan Kualitaif. Bandung: CV Alfabeta.

Susanto H. 2014. Kajian Komoditas Unggulan, Andalan dan Potensial di Kabupaten Grobongan. Journal of Rural and Development. 5(1): 63-80.

Sobari, Febrianto. 2010. Kajian Bio-Teknik Pemanfaatan Sumberdaya Ikan Tenggiri dan Distribusi Pemasarannya di Kabupaten Bangka. Maritek. 10(1): 15-29.

Tarigan RMRP. 2005. Ekonomi Regional Teori dan Aplikasi. PT Bumi Aksara: Jakarta.

Yurliana, Muhamad RR, Selamet R. 2015. Analisis Sektor Ekonomi Unggulan di Kabupaten Batanghari. Jurnal Perspektif Pembiayaan dan Pembangunan Daerah. 3(2): 115128. 